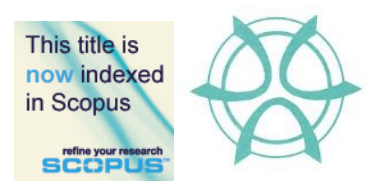

PLANNING MALAYSIA:

Journal of the Malaysian Institute of Planners

VOLUME 16 ISSUE 4 (2018), Page 55 - 67

\title{
EARLY TOWN PLANNING SYSTEM OF SMALL TOWNS IN PERAK
}

\author{
Mohd Jaki Mamat ${ }^{1}$ \& Muhammad Firzan Abdul Aziz ${ }^{2}$ \\ ${ }^{1 \& 2}$ School of Housing Building and Planning \\ UNIVERSITI SAINS MALAYSIA
}

\begin{abstract}
The township planning in Perak was affected post-signing of the Pangkor Treaty in 1874, as the state became the first state in Malaysian Peninsula intervened by the British. Introduction of grid system by the British has apparently affected the early layout of major cities such as Ipoh, Taiping, Kuala Lumpur, George Town and Singapore. This study attempts to investigate the theory of town planning during the British era after noticing a knowledge gap in regard to early town planning system of small towns in Perak. Based on purposive sampling using varying topographies as the criterion of site selection, 10 out of 20 small towns in Perak were selected for data collection. The small towns were Kuala Kurau, Klian Intan, Bagan Datoh, Lumut, Parit, Tanjung Rambutan, Pusing, Sungkai, Padang Rengas and Lenggong. Besides measured drawings, interviews were conducted with the locals and historical manuscripts of the research locale were also revisited. Based on comparative analysis, the study found that topographical factor was insignificant in influencing the early layout of small towns in Perak since linear system was used at different topographical background (riverside, coastal, hilly terrain and flatland areas). Moreover, location factor was found to be significant in terms of influencing the arrangement of early shophouse buildings into rows, which influenced the early layout of small towns in Perak.
\end{abstract}

Keywords: linear system, shophouses, small towns 
Mohd Jaki Mamat \& Muhammad Firzan Abdul Aziz

Early Town Planning System of Small Towns in Perak

\section{INTRODUCTION}

Perak was the first state in the Malaysian Peninsula intervened by the British after the signing of Pangkor Treaty in 1874. Ever since, the formation of several towns in Perak started to appear as a consequence of the state's socioeconomic and physical development. Reportedly during the early physical development of Perak, formation of small towns (that emerged from the arrangement and concentration of shophouse buildings into rows) has brought upon health and safety issues (Home, 1997; Nasution \& Lubis, 2005). Sensitising the scenario, application of grid system at the affected sites or exploration and development of nearby areas were advocated by the British as the town re-planning measures (Nasution \& Lubis, 2005; Wan Mokhtar, 2016).

Historically, the English Town Planning Act 1932 and the British Planning Legislation 1932 were the two influential guidelines regulated by the British with regard to town planning in Malaysia (Home, 1997; Garnaut, 2004). Owing to that, the grid system was then introduced and implemented, which affected the planning of early Malaysian cities such as Ipoh, Taiping and Teluk Intan of Perak (Yuen, 2011; Wee, Yoon, \& Guan, 2014) as well as the capital city, Kuala Lumpur (Garnaut, 2004). Despite the policy enforcement, the underlying factor which caused several small towns in Perak remain unaffected in terms of their physical layout was presumably due to their average economic expansion. Acknowledging so, this paper emphasises the needs of conducting an empirical investigation on the early small towns in Perak through their rows of shophouse buildings which is regarded as the main element of town formation (Symonds, 2005). Analysis of their layout pattern and topographical correlation are deemed imperative especially when shophouse buildings are ethos from the past. Evidently, they still bear the heritage value of old township formation despite facing serious threats arising from modern development pressure, urban dereliction and high deterioration rate (Bissel, 2005; Wee et al., 2014).

\section{EARLY TOWN PLANNING}

In the past, places of religious and worshipping practices as well as residences of local community leaders have been commonly associated with the genesis of a township or traditional settlements (Lewandowski, 1975; Harun \& Jalil, 2012; Abidin, Shahminan \& Ibrahim, 2017). Later in the $19^{\text {th }}$ Century, concentration of populations and settlements shifted to places which carried out economic activities (Lockard, 1974; Ortolano, 2011). Formation of small towns then became more rampant after the influx of Chinese immigrants into the Malay Peninsula, catalysed by the Chinese merchants who actively constructed business premises and shophouses to cater their economic agenda (Lockard, 1974). Apparently, their buildings were built either in close proximity, or, within the existing settlements of the Malays' community (Wan Ali, Abdul Hadi, \& Ishak, 2015; Samsudin \& Idid, 2016). This development trend clearly differs with the 
PLANNING MALAYSIA

Journal of the Malaysia Institute of Planners (2018)

formation of early towns during the British years - in which their planning considerations did not emphasise on the significance of community factor (Yuen, 2011). Instead, the British was more concerned with safety and administration issues (Mizushima, 1997; Taylor, 2010) over business and trading activities (Garnaut, 2004; Mamat, 2016). Meanwhile in Perak, the British was more concerned with safety aspect for small towns located in distance with the state's main cities (Tilaki, Abdullah, Bahauddin, \& Marzbali, 2014; Mamat, 2014; Mamat, 2016).

Theoretically, the physical layout of townships or cities is dependent on various factors, mainly including the local economic activities (Larkham, \& Lilley, 2012) involving business centres (Wan Ali et al., 2015), agricultural products (Syed Zainol, 1995), shipping ports (Lewandowski, 1975; Hassan, 2009; Harun \& Jalil, 2012) and also land transportations such as railway and traffic networks (Ibrahim et al., 2014). Implying from that, these locations typically turned to be the focal points of their respective localities (Yuen, 2011). On the other facet, topographical condition was known to be influential towards a town's form and layout (Lockard, 1974; Mohd, Ahmad, \& Wan Abd Aziz, 2009; Shamsuddin, 2011).

In the case of Perak specifically, its town formation was also influenced by the state's natural resources and its transportation network (Ortolano, 2011; Symonds, 2005). Most of the towns in Perak are associable with the state's tin mining industry, as evidenced through its infrastructural developments such as shophouses, administration offices, labourer's residence, roads and so on (Ahmad, 2013). The policy enforced in regard to town formation upon the British arrival in Malay Peninsula was in line with Town Planning Enactment 1923 (Garnaut, 2004) and Town Planning Act 1932 (Taylor, 2010) - to address the issues of safety as well as divide and rule policy (Home, 1997; Njoh, 2008). Despite the implementation of the two legislations by the British, involvements of their town planners and architects happened only after the localities reached the states of stability and safety (Hassan, 2009). In essence, town formations in Malay Peninsula occurred primarily due to the business activities and commercial relationships between the Chinese merchants and the local Malays (Ahmad, 2013; Wan Ali et al., 2015; Mamat, 2016). This interrelationship has indirectly influenced the physical layout of Perak townships, as seen in the rows of shophouses built on the land owned by the Malays for instance (Mizushima, 1997).

The report of the Town Profile in Perak issued by the Federal Department of Town \& Country Planning Peninsular Malaysia in 2009 showed that the layouts of early towns and cities of Perak such as Ipoh, Sitiawan, Kuala Kangsar, Sungai Siput, Taiping and Teluk Intan were based on linear and grid systems. Implying from this, the report can be leveraged as a point of reference to study the early town planning system of small towns in Perak. The report finding is in 
Mohd Jaki Mamat \& Muhammad Firzan Abdul Aziz

Early Town Planning System of Small Towns in Perak

tune with Haverfield's (1913) assertion that most towns or cities initially were formed either by a straight or curvy lines (depending on the sites' topographical condition), which later merged with each other. Those lines typically were in parallel, or taking into accounts of the layout of the existing settlements (Lewandowski, 1975). This is in line with Taylor (2010) who posited that the evolvement of a township is commonly based on the offset of its settlements' arrangement in the forms of centralised, linear and etc. In this manner, groups of shophouse that row along streets eventually led to the formation of a town (Garnaut, 2004).

Most of the architectural design and built of shophouse buildings found in Perak originated from the mainland of China (Shamsuddin, 2011). With main road as their frontage and back lane at their rear side, the rows of shophouse basically correspond to the linear town planning system (Wan Ali et al., 2015). This is in contrast with the British town planning concept in the use of grid system which emphasised segregation of land based on their functions such as administration, commercial, residential (Hassan, 2005; Shamsuddin, 2011), recreational (Bissell, 2005; Harun \& Jalil, 2012) and logistical (Ibrahim et al., 2014) zones. Besides facilitating the conurbation process (Harun \& Jalil, 2012), implementation of the grid system also supported the divide and rule policy applied by the British, especially for the purpose of social segregation based on race and status (Bissell, 2005; Hassan, 2009).

Based on the literature review, it is found that the early layout of towns or cities was influenced by their respective existing settlements. Apart from that, other influential factors include land topologies, economic activities and logistics. Only after the British arrival, town planning approach in Perak has shifted to the grid system following the land segregation and zoning purposes. This historical fact is thus imperative as point of reference to further understand the early small town planning system through data collection conducted at 10 selected small towns in Perak.

\section{METHODOLOGY}

Measured drawing was used as a methodological means in the present study to identify and record the early layout of small towns in Perak. Using topographical factor as the criterion of purposive sampling, 10 small towns were selected from the total of 20 small towns available in Perak. Topographical characteristics involved in the study include riverside, coastal, hilly terrain and flat land areas. The small towns selected are namely Bagan Datoh, Lumut, Klian Intan, Kuala Kurau, Parit, Tanjung Rambutan, Lenggong, Pusing, Padang Rengas and Sungkai. Past manuscripts and writings were used to validate the early row of shophouses. However, studies on small towns were sparsely carried out relative to the numbers of documentations done on major cities. This is considerably a limitation of the current study. 
PLANNING MALAYSIA

Journal of the Malaysia Institute of Planners (2018)

Hence, acquisition of primary data through interviewing the locals was essential to complement the secondary data in validating the early row of shophouses. Interviewees were sampled based on their current position at the research locale (chief villager or head of the community), relationship with the buildings (owner and end-user), and knowledge or familiarity with the subject matter (historian or local figure). The entire shophouses from the 10 small towns identified were then further analysed to determine their sizes, number of units and locations. Subsequently, the information gathered was matched with plans based on PerakGIS (Geographic Information Systems) issued by the Federal Department of Town \& Country Planning Peninsular Malaysia. Layouts of the small towns were then reproduced digitally using AutoCAD software to carefully examine and analyse the early town planning system. To narrow down the scope of the study, only linear and grid town planning systems were looked into as the indicator of early town formation. Other town planning systems such as clustered or scattered were left out from the current study considering that these systems contradict with the nature of shophouse characteristics (which physical arrangement is based on rows).

\section{MALAYSIA}

Perak

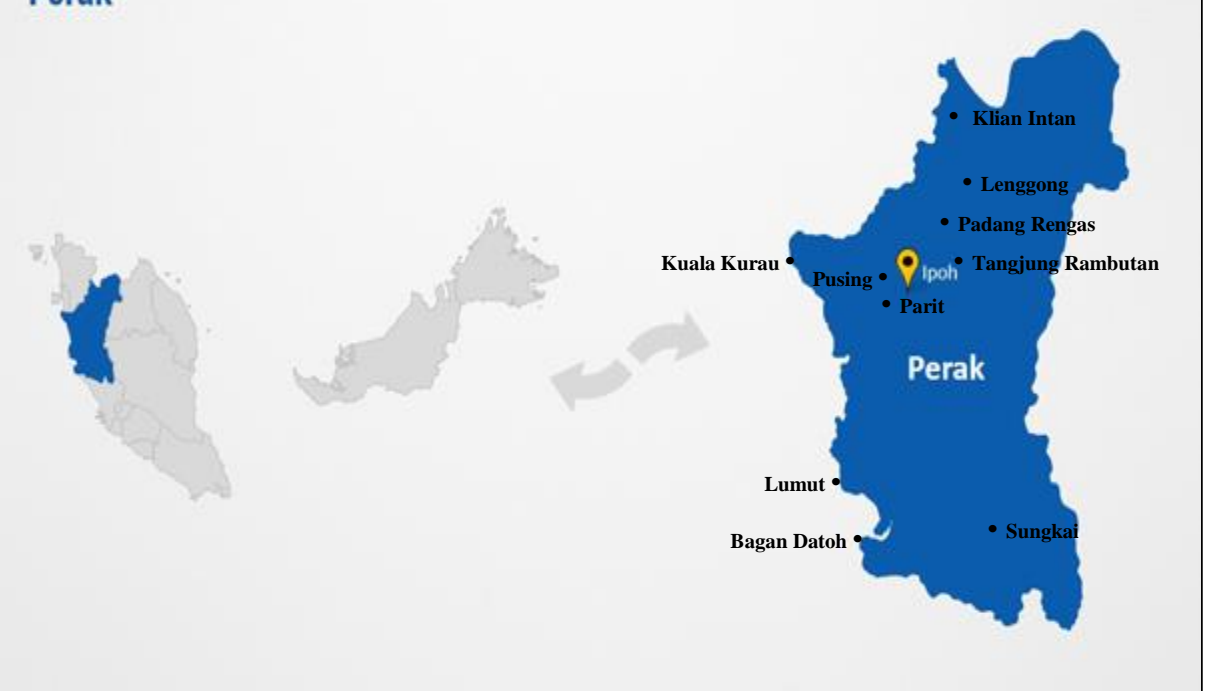

Figure 1: Location of selected small town in Perak, Malaysia Source: Google Image 
Mohd Jaki Mamat \& Muhammad Firzan Abdul Aziz,

Early Town Planning System of Small Towns in Perak
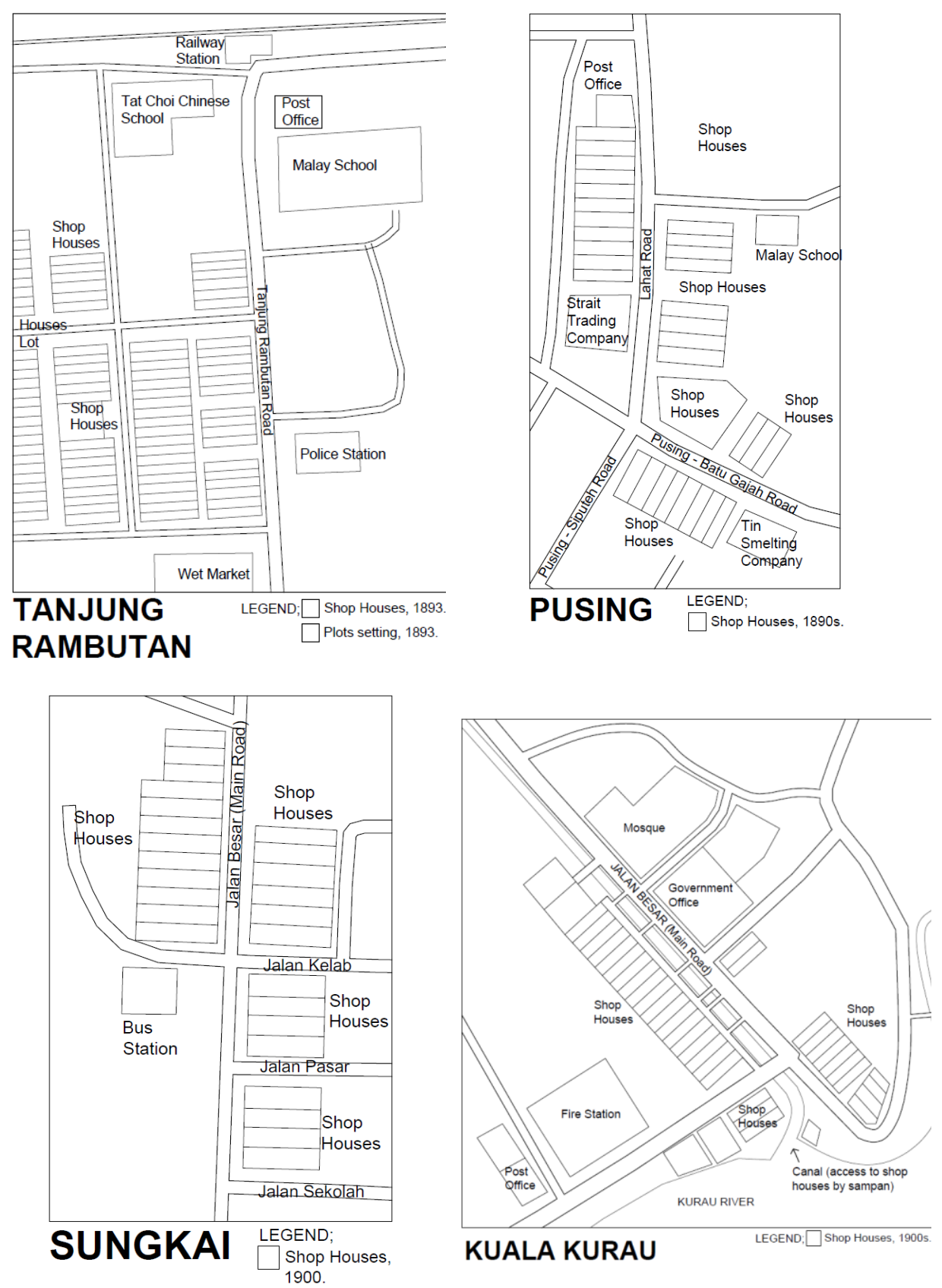

(C) 2018 by MIP 
PLANNING MALAYSIA

Journal of the Malaysia Institute of Planners (2018)

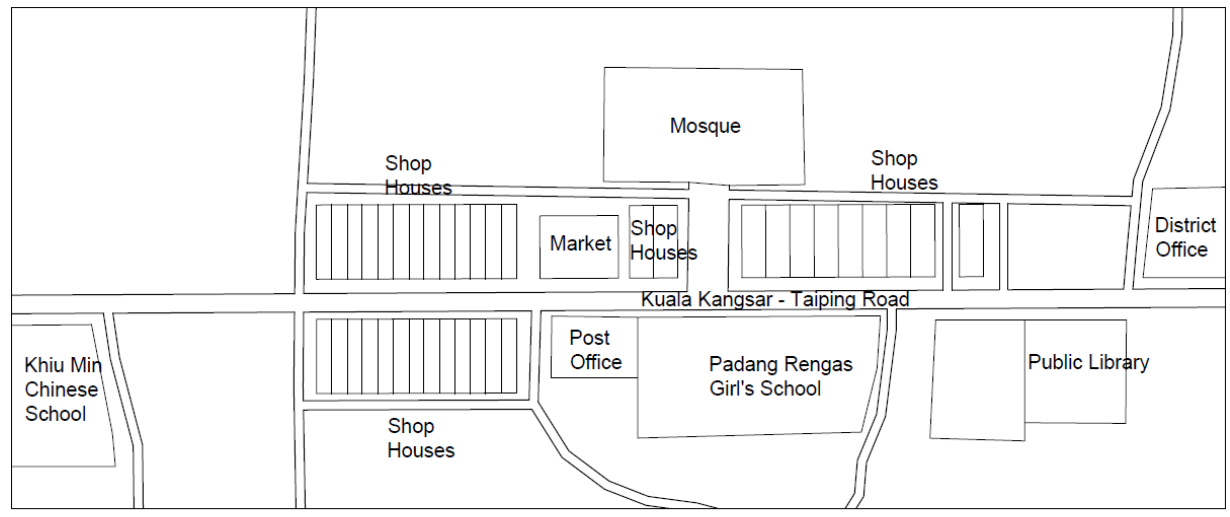

PADANG RENGAS
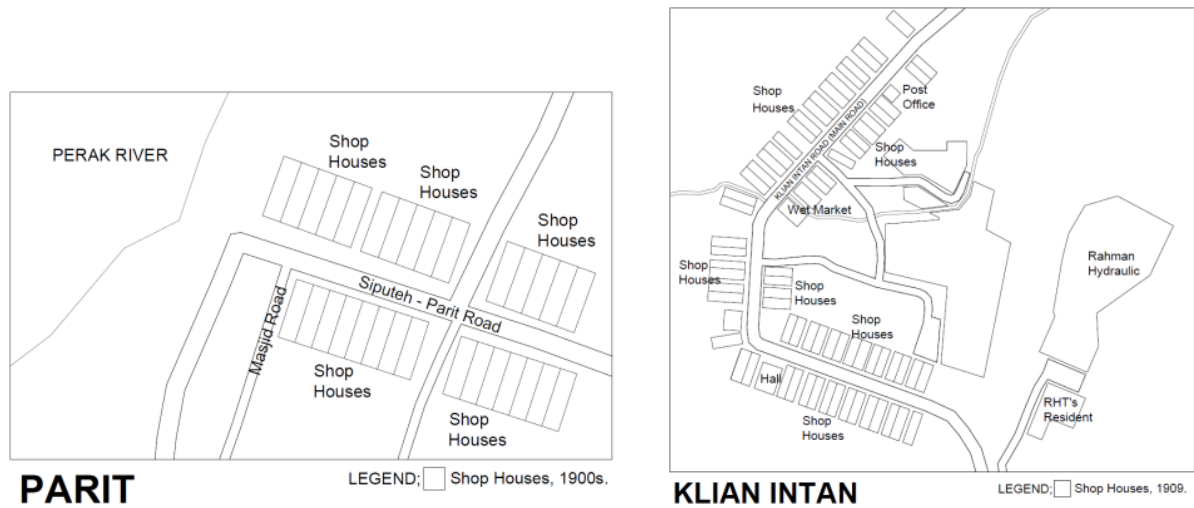

PARIT

KLIAN INTAN

LEGEND; $\square$ Shop Houses, 1900s. 


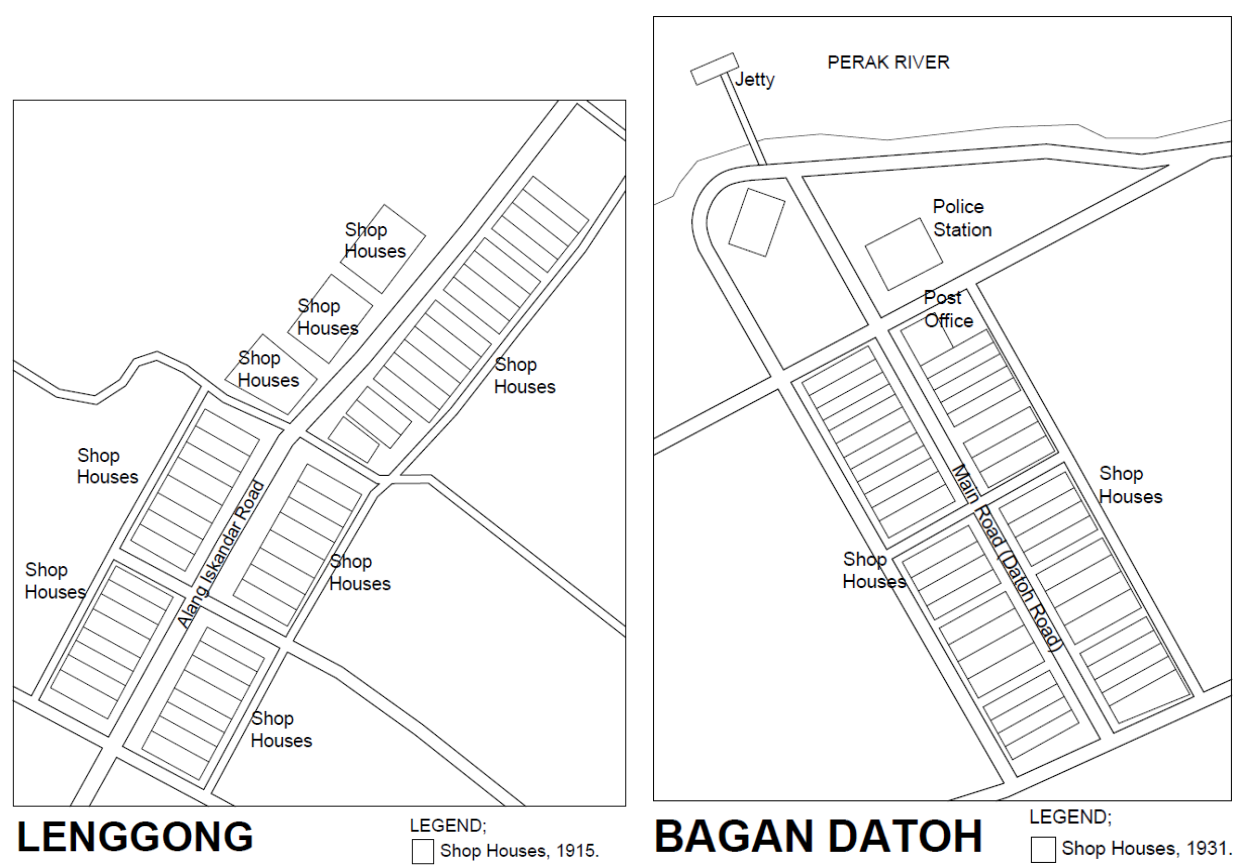

Figure 2 - Figure 11: Layout plan of the selected small towns in Perak

\section{ANALYSIS AND FINDINGS}

Based on scrutiny on the early layouts of 10 small towns in Perak as shown in Figure 2 to Figure 11, it was found that the grid system was merely applied to one of the small towns - Tanjung Rambutan. The underlying reason for this scenario can be associated with the British effort in developing a new township to replace the old Tanjung Rambutan, in the quest to cater its cleanliness issue apart from complementing its infrastructural needs of railway transportation that started operation in 1896. The old layout of Tanjung Rambutan however, is unknown, and irretrievable after the fire tragedy which occurred in 1897 that destroyed earlier records. The planning of a new Tanjung Rambutan township since 1893 by the British was based on the positioning of shophouse rows flanking the main roads, with residential buildings allocated at the rear side of shophouse buildings.

On the other hand, nine out of the 10 small towns studied were found to be based on the linear concept of town planning. Ironically, some of them were even mining towns such as Pusing and Klian Intan, featured with the existence of various facilities such as shophouses, post office, labour residence, police station and market. Sungkai, Padang Rengas, Kuala Kurau, Lenggong, Parit and Bagan Datoh, meanwhile, were the five small towns that evolved from their agricultural industry. The other small town found without the grid system was Lumut. The linear system was notably more practical for Lumut - a town that mainly functioned as a port together with Pulau Pinang, Melaka and Singapura 
PLANNING MALAYSIA

Journal of the Malaysia Institute of Planners (2018)

(collectively known as the Straits Settlements, governed by the British during 1874 until 1934), despite the segregation of commercial and administration (district office, residence of British officers, hospital etc.) zones at that time.

This study also found that topological factor was insignificant in influencing the town planning of the early layout of the small towns in Perak. This is rationalised by the use of linear system despite the existence of various topography conditions such as riverside, coastal, hilly terrain and flatland areas. Although the linear system is theoretically suitable for hilly terrain areas such as in Lenggong and Klian Intan following the difficulty to do the offset on rows of shophouses, it ironically was also used to flat land areas as seen in Pusing, Sungkai and Padang Rengas. Even more, the linear system was also used at flat land areas in close proximity to riverside and coastal areas such as in Kuala Kurau, Lumut, Parit and Bagan Datoh. This particular finding thus testified that the linear system was used for the early town planning system of small towns in Perak regardless of their topological factor.

In addition, this study also found that the early shophouse buildings were collectively built by the Malays (in Sungkai, Pusing and Padang Rengas), the Chinese (in Kuala Kurau, Lenggong, Parit, Bagan Datoh and partially in Pusing) and the British (in Tanjung Rambutan, Klian Intan and Lumut). In light of this, the British interventions in the local construction history were not limited to administrative, residential, public and military buildings, but also include commercial premises. This study also revealed that in terms of land ownership, the initiation stage of townships was built on the land owned by the Malays especially in Pusing, Padang Rengas and Lengong. Merely land of shophouses at Kuala Kurau was found to be owned by the Chinese. Imperatively, the British was involved in determining and dividing the lots for constructing shophouses at that time.

Based on the interviews, it was found that the entire rows of shophouse building existed simultaneously with the main roads (reportedly not paved during their early stage). Then, the British contributed to provide a better infrastructure by reconstructing proper roads equipped with drainage system. Other facilities included post office, police station, recreational field, market and so on. Table 1 summarises the overall findings with regard to early town planning system of small towns in Perak. 
Mohd Jaki Mamat \& Muhammad Firzan Abdul Aziz

Early Town Planning System of Small Towns in Perak

Table 1: Early town planning system of small towns in Perak

\begin{tabular}{|c|c|c|c|c|c|c|}
\hline Town & $\begin{array}{l}\text { First } \\
\text { built }\end{array}$ & $\begin{array}{l}\text { Builder } \\
\text { (owner) }\end{array}$ & Land owner & Topology & Economy & $\begin{array}{l}\text { Layout } \\
\text { system }\end{array}$ \\
\hline $\begin{array}{l}\text { Tanjung } \\
\text { Rambutan }\end{array}$ & 1893 & British & British plots & $\begin{array}{l}\text { Flat land - } \\
\text { riverside }\end{array}$ & $\begin{array}{l}\text { Tin mining/ } \\
\text { railway station }\end{array}$ & $\begin{array}{l}\text { Grid - rows of } \\
\text { shophouses on } \\
\text { both side of } \\
\text { the main road }\end{array}$ \\
\hline Pusing & $1890 \mathrm{~s}$ & $\begin{array}{c}\text { Local } \\
\text { Malay and } \\
\text { Maindailing } \\
\text { /Chinese }\end{array}$ & $\begin{array}{l}\text { Local Malay } \\
\text { /Maindailing }\end{array}$ & Flat land & Tin mining & $\begin{array}{l}\text { Linear }-2 \text { row } \\
\text { shophouses on } \\
\text { one side of the } \\
\text { main road }\end{array}$ \\
\hline Sungkai & 1900 & $\begin{array}{c}\text { Local } \\
\text { Malay \& } \\
\text { Chinese }\end{array}$ & Unknown & Flat land & $\begin{array}{c}\text { Agriculture/ } \\
\text { railway station }\end{array}$ & $\begin{array}{l}\text { Linear }-2 \\
\text { rows } \\
\text { shophouses on } \\
\text { both sides of } \\
\text { the main road }\end{array}$ \\
\hline $\begin{array}{l}\text { Padang } \\
\text { Rengas }\end{array}$ & $1900 \mathrm{~s}$ & $\begin{array}{l}\text { Local } \\
\text { Malay }\end{array}$ & Local Malay & Flat land & Agriculture & $\begin{array}{l}\text { Linear }-4 \text { row } \\
\text { shophouses on } \\
\text { both sides of } \\
\text { the main road }\end{array}$ \\
\hline $\begin{array}{l}\text { Kuala } \\
\text { Kurau }\end{array}$ & $1900 \mathrm{~s}$ & Chinese & Chinese & $\begin{array}{l}\text { Coastal area } \\
\& \text { riverside }\end{array}$ & $\begin{array}{l}\text { Fishery \& } \\
\text { agriculture }\end{array}$ & $\begin{array}{l}\text { Linear }-1 \text { row } \\
\text { shophouses on } \\
\text { one side of the } \\
\text { river }\end{array}$ \\
\hline Lenggong & 1915 & Chinese & Local Malay & Hilly terrain & Agriculture & $\begin{array}{l}\text { Linear }-2 \text { row } \\
\text { shophouses on } \\
\text { one side of the } \\
\text { main road }\end{array}$ \\
\hline Klian Intan & 1909 & British & British plots & Hilly terrain & Tin mining & $\begin{array}{l}\text { Linear - semi- } \\
\text { detached } \\
\text { shophouses on } \\
\text { one side of the } \\
\text { road }\end{array}$ \\
\hline Lumut & $1920 \mathrm{~s}$ & British & British plots & Coastal area & Port & $\begin{array}{l}\text { Linear }-2 \\
\text { rows } \\
\text { shophouses on } \\
\text { both sides of } \\
\text { the main road }\end{array}$ \\
\hline Parit & 1928 & Chinese & British plots & Riverside & Agriculture & $\begin{array}{l}\text { Linear }-2 \\
\text { rows } \\
\text { shophouses on } \\
\text { both sides of } \\
\text { the main road }\end{array}$ \\
\hline $\begin{array}{l}\text { Bagan } \\
\text { Datoh }\end{array}$ & 1931 & Chinese & British plots & $\begin{array}{l}\text { River and } \\
\text { coastal area }\end{array}$ & Agriculture & $\begin{array}{l}\text { Linear - rows } \\
\text { of shophouses } \\
\text { on both sides } \\
\text { of the main } \\
\text { road }\end{array}$ \\
\hline
\end{tabular}

*Maindailing is one of the Malay ethnics originated from Sumatera, Indonesia 
PLANNING MALAYSIA

Journal of the Malaysia Institute of Planners (2018)

\section{CONCLUSION}

To conclude, the linear system was used in the early town planning system of small towns in Perak. In consolidating the claim, there were no land lots found available for adding more premises (land expansion based on the grid planning system) at the sites under this study. This finding is supported by both primary (interviews conducted) and secondary (document review) data acquired pertinent to the 10 small towns in Perak. Despite the introduction of the grid system by the British for the planning of major cities in Perak, it was not applied in the planning of small towns. Instead, the linear system was adopted and implemented by the British following its practicality in the planning of small towns which are relatively smaller in size compared to cities. Despite so, the uses of grid system for land expansion are still found today in towns such as Pusing, Bagan Datoh, Lumut, Parit, Lenggong, Sungkai and Kuala Kurau. Nevertheless, its implementation is merely found on new sites located away from the immediate surroundings of the earliest rows of shophouse.

Apart from the British interventions in town and city planning, this study also acknowledges the equal role played by the local Malays and Chinese merchants. In particular, there was a technical relationship existed between the local Malays and Chinese merchants in terms of provision of lands and construction of premises, thus influencing the location and layout pattern of the early row of shophouses of the small towns in Perak. Conclusively, the layout of small towns in Perak was influenced mainly by commercial activities, through the building of shophouses by Chinese merchants on the lands owned by the local Malays. The small towns in Perak basically emerged as a result from the centralisation of the existing Malays' settlements as well as the new settlements formed by the Chinese immigrants who ran the tin mining industry.

\section{ACKNOWLEDGEMENT}

The authors would like to acknowledge the Town and Country Planning of Perak (Federal Department) for funding the current studies under the project grant received in 2015 and 2016. Special credits also go to the lecturers and students of Ungku Omar Polytechnic, Perak Heritage Society (PHS), local councils and district offices, local communities, respective building owners and individuals who have directly and indirectly contributed in the process and conduct of this study.

\section{REFERENCES}

Abidin, N. Z., Shahminan, R. N. R., \& Ibrahim, F. K. (2017). Architectural influences of Istana Lama Seri Menanti, Negeri Sembilan. Planning Malaysia, 15(1), 151162.

Ahmad, S., \& Jones, D. (2013). Investigating the mining heritage significance for Kinta District, the industrial heritage legacy of Malaysia. Procedia - Social and Behavioral Sciences, 105, 445-457. 
Mohd Jaki Mamat \& Muhammad Firzan Abdul Aziz

Early Town Planning System of Small Towns in Perak

Bissell, W. C. (2005). Engaging colonial nostalgia. Cultural Anthropology, 20(2), 215248.

Federal Department of Town \& Country Planning Peninsular Malaysia (2009). Perak town profile report. Ipoh: Author.

Garnaut, C. (2004, July). Chronicles from the Far East: The garden city model of planning in the Federated Malay States, 1920-1929. 11th Conference of the International Planning History Society (IPHS). July 14-17, 2004, Barcelona, Spain.

Harun, N. Z., \& Jalil, R. A. J. (2012). The morphological history of the Malaysian urban form. International Proceedings of Economics Development and Research, 48(24), 111-116.

Hassan, A. S. (2009). The British colonial 'divide and rule' concept: Its influence to transport access in inner city of Georgetown, Penang. Transportation, 36, 309 324.

Hassan, A. S. (2005). Rekabentuk bandar di Semenanjung Malaysia. Penang: Penerbit Universiti Sains Malaysia.

Haverfield, F. (1913). Ancient town-planning. London: Oxford University Press.

Home, R. (1997). Of planting and planning: The making of British colonial cities (1 ${ }^{\text {st }}$ edition). London: Chapman \& Hall.

Ibrahim, M. H., Baharom, A. A., Ariffin, K., Jabar, B., Marzuki, M., \& Kamaludin, K. (2014). Investigation of the landscape change in old Malaysian railways: Special references to Port Weld-Taiping railway. The Social Sciences, 9(5), 357-361.

Larkham, P., \& Lilley, K. (2012). Exhibiting the city: Planning ideas and public involvement in wartime and early post-war Britain, Town Planning Review, 83(6), 647-668.

Lewandowski, S. J. (1975). Urban growth and municipal development in the colonial city of Madras, 1860-1900. Journal of Asian Studies, 34(2), 341-360.

Lockard, C. A. (1974). The Southeast Asian town in historical perspective: A social history of Kuching, Malaysia, 1820-1970 (Doctoral dissertation). University of Wisconsin, USA.

Mamat, M. J. (2016). Lenggong: World Archaeology Heritage Town. Ipoh: Federal Department of Town \& Country Planning Peninsular Malaysia.

Mamat, M. J. (2014). Papan: The oldest mining town in Kinta. Ipoh: Federal Department of Town \& Country Planning Peninsular Malaysia.

Mizushima, T. (1997). A historical study on land transaction in a local town in Malaysia Kuala Kangsar shop lots between 1885 and 1995. Regional Views, 10, 81-111.

Mohd, I., Ahmad, F., \& Wan Abd Aziz, W. N. (2009). Exploiting town planning factors in land development: Case study of urban housing in Kuala Lumpur, Malaysia. Journal of Facilities Management, 7(4), 307-318.

Nasution, K. S., \& Lubis, A. R. (2005). Kinta Valley: Pioneering Malaysia's modern development. Ipoh: Perak Academy.

Njoh, A. J. (2008), Colonial philosophies, urban space and racial segregation in British and French Colonial Africa. Journal of Black Studies, 38(4), 579-599.

Ortolano, G. (2011). Planning the urban future in 1960s Britain. The Historical Journal, 54(2), 477-507. 
Samsudin, N. A., \& Idid, S. Z. A. (2016). Influences of housing settings and designs in fulfilling the Malay residents' social cultures. Planning Malaysia, 4(Special Issue), 109-120.

Shamsuddin, S. (2011). Townscape revisited: Unravelling the character of the townscape in Malaysia. Skudai: Penerbit UTM Press.

Symonds, J. (2005). Dirty old town? Industrial archaeology and the urban historic environment. Industrial Archaeology Review, XXVII(1), 57-65.

Taylor, N. (2010). Commentary: What is this thing called spatial planning? An analysis of the British government's view. Town Planning Review, 81(2), 193-208.

Tilaki, M. J. M., Abdullah, A., Bahauddin, A., \& Marzbali, M. H. (2014). The necessity of increasing livability for George Town World Heritage Site: An analytical review. Modern Applied Science, 8(1), 123-133.

Wan Ali, W. N., Abdul Hadi, N. H., \& Ishak, N. R. (2015, October). An overview on the typology of shophouses' façade at the heritage area in Ipoh City. Postgraduate Conference on Global Green Issues (Go Green),UiTM (Perak). October 7-8, 2015, Perak, Malaysia.

Wan Mokhtar, W. N. H. (2016). Tanjung Rambutan; A serene town at the foot of Mount Korbu. Ipoh: Federal Department of Town \& Country Planning Peninsular Malaysia.

Wan Mokhtar, W. N. H. (2015). Bagan Datoh; The earliest coconut plantation town. Ipoh: Federal Department of Town \& Country Planning Peninsular Malaysia.

Wee, L. H., Yoon, K. T., \& Guan, G. G. (2014). Revitalisation of the old township of Ipoh, Malaysia. Journal of Place Management and Development, 7(1), 57-73.

Yuen, B. (2011). Urban planning in Southeast Asia: Perspective from Singapore. Town Planning Review, 82(2), 145-167.

Received: $1^{\text {st }}$ June 2018. Accepted: $1^{\text {st }}$ December 2018 